\title{
CAN IDENTIFICATION AND BRANDING AUGMENT EMPLOYEE ENGAGEMENT? AN EMPIRICAL ANALYSIS
}

\author{
Himayat Ali \\ Research Scholar, National Defence University, Islamabad \\ himayatnuml@gmail.com \\ Muhammad Zia-ur-Rehman \\ Associate Professor, Department of Leadership and Management Studies, \\ National Defence University, Islamabad \\ drziaofficial@gmail.com \\ Adnan Jamil \\ Assistant Professor, Department of Leadership and Management Studies, \\ National Defence University, Islamabad \\ adnan.@ndu.edu.pk
}

\begin{abstract}
The focus of the research is to analyse the role of Branding and Identification on Engagement. This paper gives a survey of the current evidence on such relationship and offers recommendations for additional investigations. A broad review of the existing body of knowledge relevant literature to the subject has been attempted to establish an association among Internal Branding, Organizational Identification and Employees Engagement in Telecom Sector of Pakistan. Fewer studies have been carried out that discovered positive affiliations while others negative and a few no affiliations at all. Here we employed the case study of telecom sector of twin city of Pakistan and the study used primary data of the middle level managers collected through self-administrated questionnaire. The study was carried out on non-probability convenience sample size of 271 from the respondents at supervisory and mid-level, managerial positions of five different telecom organizations of Rawalpindi/Islamabad. Regression analysis was applied to verify the hypotheses of study. The study concluded by identifying that there is vital and significant impact of Internal Branding \& Organizational Identification on Employees Engagement.
\end{abstract}

Key Words: Identification, Branding and Engagement Empirical Analysis

\section{INTRODUCTION}

In past few years Employee Engagement is known as important research variable in any firm. It is a cause of boundless concern for the various organizations for their financial support and find out the reason about that academic phenomenon why the academic phenomena are too stressed in equal measure between academia and professionals. Researchers consider employee involvement as a condition in which the worker efforts about the involve himself to performed of his duties as a reimbursement of the available resources; he was given by the organization (Kahn, 1990). Engagement is accomplished with the support of attention and integration. Usually, Concentration depends on cognitive aptitude which means the duration of period. The worker devotes their time to observe and integrate indicates the strength of the worker concentration (Rothbard et al., 2001). Basically, Employee Engagement is about the quantifiable position of any workers toward their attachment about his or her role they are playing in the organization. According to Hater et al., (2002) Employee Engagement is only about the pleasure and the connection of the employees toward the task given by their supervision in any firm.

The Telecom Sector is known, as the one of the fastest rising sectors in the economy of Pakistan and its contribution is very significant in all aspects in development. When there is development in Telecom sector there arise difficulties in this sector also. The one of the biggest hovering problems is the Employee Engagement (Krishnan, 2012). Organizational identification and 
internal branding are important factors in the current that improve Employee Engagement and that's way it considers one of the important sectors to overcome this problem of which is known as Employee Engagement. With the absence these issues will decrease the Employee Engagement on the way to the job of staff in the Telecom Sector which is measured being the negative influence toward the Employee's Engagement. The main reason many specialists' efforts to solve the entire problem. This is main reason this sector considers most value able for any economy, while also discovering all probable all ways to rise achievement in the sector of Telecom sector. The study was carried out to examine impact of organisational identification and internal branding on employee's engagement, and to provide a general opinion on how employee engagement influences the telecom sector. Furthermore, this research also has additional assistance telecom in management of sale to comprehend the value of employee engagement (EE) and find out the elements which help to increase the objects in any firm to increase the engagement stage in their employees working in sales area. Additionally, this is the thought that Organizational Identification and Internal Branding can further elaborate and help to recognize the position of these concepts nurturing the level of engagement of manager level of Telecom sector of Pakistan in general and particularly Rawalpindi/ Islamabad.

\section{REVIEW OF LITERATURE}

Based on social identity theory, it can be said that the association has its roots in community documentation as Social Identity Theory (SIT) is a societal psychosomatic phenomenon of collection affiliation, collection procedures, and finally inter collection relationships. Social identity theory places particular emphasis on the part of self- classification in the cases, along in twined ideas and sub-concepts from another field of collective life. The fundamentals of the study were initially introduced in the early 1970's by Henri Tajfel, and since then it has become, as stated by Hogg (2006), one of the most important theories in social psychology of the association between group and self. Community character the concept is founded on the awareness that the community group (such as population, athletic squad, and workgroup) in which one falls or feels one belongs, confers specific features on the actual category, and thus becomes part of the individual, Self-concept. It states that people own many of these categorical social associations, in a group or a collection of groups, of different importance and prominence. First scholar in People and Humanity (Berger, 1966) has explained this affiliation fine: "The individual realizes himself in society that is; he recognizes his identity in socially defined term and these definitions becomes reality as he or she take breath in society".

\section{Organizational Identification}

According to Ashforth and Mael (1989), organizational documentation is a formal arrangement of the community documentation model, in which an entity's character is derived from his or her organization's common groups, or community groups. The community collection is defined as "a group of people who consider them to be members of the same social category" (Turner, 1979), people who describe, investigate, and evaluate. Themselves in accordance with the tag possessions with the exact collection. The rules of comportment related with the collection serve as a pure pathway for the performance of members.

\section{Internal Branding}

Internal branding, in an administrative viewpoint, is well-defined as "the way that employees can relate to each other, be part of something, part of a unity, an image, and that everything I do or say to a consumer or to another employee in the organization, I am representing that image" (Blumenthal, 2001). Due to the detail that this explanation signifies a management perception, the notion of agreement and compliance with the interior product is familiar. A durable interior branding policy is very beneficial for relations with interior investors, as it can also improve identity with the association and also make wisdom of union with workers and the other society (Einwiller, 2001).

A durable wisdom of harmony and a great equal of documentation unqualified the durable basis for inspiration and presentation, as well as for actual organization inside the group. Though, from the perspective of HRM, interior labeling can be observed in an extra planned time, as the shared 
sympathetic of the way of the society by its staffs can be highly underlined. In other meaning, interior labeling from this view means that people in the organization know what the organization is, what it does and where it is headed in the future, and that people are aligned with the organization's strategic goals (Blumenthal, 2001). This definition comprehensively and strongly emphasizes the ideas of matching and harmonization. In this regard, the reconciliation process ensures high productivity when employees at all levels of management understand and accept the authenticity of organizational values; reconcile their attitudes and behavior towards brand values. Therefore, it leads to better fulfilment for both customers and staffs, which in chance principals to worker and consumer preferences and value. On the other hand, the transportations perception of interior labeling resources certifying the association's repute is reliably raising with administrative ethics, or even defensive the association's status between the interior shareholders.

This explanation focuses on the idea of status offered by business product classifications, so enhancing the link between company labelling and interior labeling product must be uttered in the similar way, regardless of the viewers whether it is exterior or interior, therefore done the administrative nation. Since this explanation it is decided that commercial administrations of the current marathon which aim to generate and tolerate their cheap benefit with cohesive statement, precisely labeling creativities, recognize the significance of including interior labeling methods into the association, to convert behaviors at the specific equal and the values at the extensive equal.

\section{Employee Engagement}

Employee engagement is a positive state of mind associated with a person's employment that consists of passion, vitality, and absorption (Bakker, 2002). It is a more determined and perceptive behaviour that focuses on the total conduct of an organization's workforce rather than just one person. According to some researchers, there are three components to work engagement (Schaufeli, 2020). At work, vigor or strength refers to when an employee demonstrates a high level of spiritual strength and adaptability, as well as the willpower and capability to devote effort, time, and energy to his or her task. Workers are energized by job-related tasks and feel strong and active at work. Commitment is the devotion and promise to work that allows people to experience arrogance and motivation in their work while also providing a sense of test and achievement via the completion of job-related duties. Their profession provides them with encouragement, and they take pride in the work they do. The third level of employee involvement is engagement, which reflects how enthralled, a person is by something.

There is lot of researches on engagement but the combination of these variables not study from last couples of years. The Employee Engagements with reverence to unique combination of Independent Variables in developing countries as well (Gala et al., 2020) Others also discusses in his study that Employee Engagement issues are still prevailing in Telecom's sector. This study is conducted on the middle manager having minor supervisory role in telecom sectors of Rawalpindi/Islamabad. Furthermore, the organizational identification and internal branding on employee engagement has not fully explored by the researchers previously, so it tends to fill the research gaps.

\section{THEORETICAL FRAMEWORK}

It is based on the three variables organisational identification, internal branding and employees' engagement. Also based on the literature and existing theories, hence, the following model is presents.

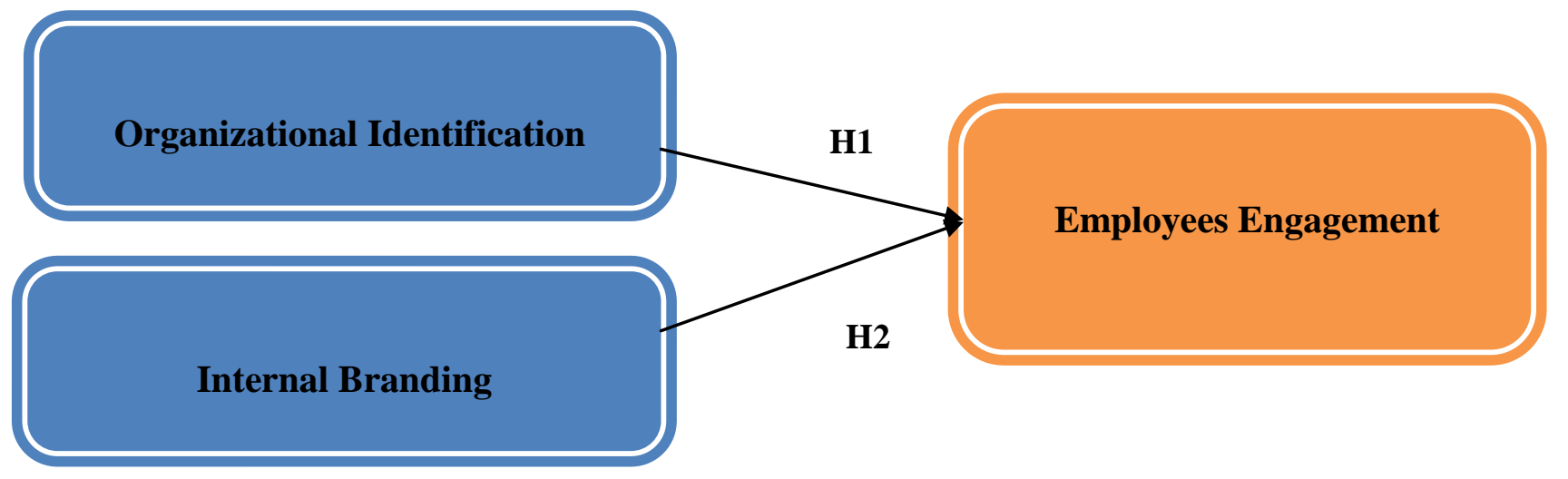


Three variables, Organizational Identification, Internal Branding, and Employee Engagement are depicted in the diagram above. Employee engagement is a dependent variable with two independent variables: organisational identification and internal branding. The have positive and strong relationship among the variables. Hence, the following hypotheses:

H1. There is a positive \& significant impact of organizational identification on employees' engagement.

H2. There is a positive and significant impact of internal branding on employees' engagement.

\section{METHODS AND MEASURES}

The study is co-relational in nature and based on quantitative analysis, in which a determination about to make a relationship between internal branding (IV), and organizational identifications (IV) and employee's engagements (DV). In this segment of research work, research methodology and data collection will be discussed as how variables are operationalized and further their statistical analysis has been carried out. The data gathering methods and procedures, sample selection, data collection, and data collection methodologies are all covered in the research design. The most valuable item in the development of an adequate and appropriate research is to undertake a data analysis. As stated by Rajasekar et al (2013), research methodology is the solution of every problem in step-by-step process. It is known how to solve any problem. In particular, the technique research describes, predicts and assumes the work consider as research methodology. He also found that the research method is a means of ahead extraordinary data. If the researcher chooses the wrong search method, not only will it appear or an inappropriate result will come out, but the research effort will also be wasted and therefore this search may prove ineffective and ineffective.

An important part of any research is its methodology that is the part of the study that provides a complete measure, methodology and analysis to be carried out while studying for research, so the aim of this chapter is to complete evaluation to be provided. To find out the answer the question about how and why procedures and procedures should be performed in the analyzation of collected data from the target population, along with the facts about data collection and analysis. The theoretical framework proposed this study not only supports in the facilitation of variable relationships, but also aims to substantiate the advanced hypothesis. For the collection of primary data, a cross -sectional study design for the application of structured questionnaire.

\section{Sampling}

Non-probability convenience sampling techniques were employed to collect the data. It was used to gather information and is a type of non-probability sampling. The study focuses on middle-class employees in the telecommunications sector in Rawalpindi/ Islamabad, as they are responsible for determining the level of innovation applied within the organization. It also saves time and is cheaper, and article data is more accessible. A total of 350 self-disciplined questionnaires were distributed among respondents and 310 were returned, making the number appropriate as recommended and 39 questionnaires were dropped finally useable 271 questionnaires was usable. The overall response rate was about $88.5 \%$. Overall response rate is as under.

\begin{tabular}{lc}
\hline & Response Rates \\
\hline Questionnaires floated & 350 \\
Returned & 310 \\
Response rate & $88.5 \%$ \\
Dropped Questionnaires & 39 \\
Finally useable Questionnaires & 271 \\
\hline
\end{tabular}


The study adopted that unit of analysis was middle manager/ supervisor for sale area. To study the relationship of the theoretical framework, employees of the following telecommunications companies were selected to collect statistical information from Mobilink, Ufone, Warid, Zong and Telenor. From the telecommunications sector mentioned above in Rawalpindi and Islamabad. The questionnaires were distributed uniformly to the telecommunications companies. The questionnaire was used to learn more about organizational identity, internal branding and employee engagement at Rawalpindi Telecom Islamabad, Pakistan. The systematic survey was conducted from various sources, visited the five telecom companies, and sent via WhatsApp and other emails asking them to complete the survey. It is guaranteed that the data collected will be used for educational purposes only and all information will be kept confidential.

Statistical Package for the Social Sciences (SPSS) 21 software will be used for quantitative data analysis. SPSS is best used to check statistics such as registration analysis and connection trends. Regression analysis can be used to determine the relationship between dependent and independent variables, while to study the relationship between different variables under study, variable analysis is useful to check the association between variables. SPSS was used to analysis the data into a fully descriptive statistical expression and to verify the reliability of the chosen tool.

\section{Data Analysis}

The study uses descriptive analysis to describe the basic characteristics of the data. They provide a simple summary of the modules and steps. In addition to simple graphical analysis, they are the main default form of quantitative data analysis. Through descriptive analysis, a person simply makes a statement about what the data is or what it represents. Statistical interpretations are needed to determine the normal distribution. Data definition is important because the nature of the technique used in meaningless data analysis depends on the characteristics of the data.

Table - 1 Descriptive Statistics

\begin{tabular}{cccccc}
\hline & Age & Gender & Education & Experience \\
\hline N & Valid & 271 & 271 & 271 & 271 \\
& Missing & 0 & 0 & 0 & 0
\end{tabular}

Descriptive analysis was performed to determine the likelihood of unknown individuals and to check for unusual differences in the information there were 271 cases that were considered valid for the study. The frequency distribution, mean, and standard deviation obtained results indicate the accuracy of data submission. In this study, by monitoring the respondents personally, missing values were deleted. Not all requests with missing values are placed on the SPSS sheet. Therefore, the current data for this study are free of missing values.

Characteristics of employees working in the Pakistani services sector are commonly measured by demographic variables. The following demographic factors are included in this study: Gender, i.e., male, and female respondents. Age provides features for examining respondents' ages, such as 22-30 years, 31-40 years, 41-50 years, and above. Thirdly, it contains experience of job i.e., 5years less, 610years, 11-15years, and above 16years lastly Educational Qualification i.e., Matric, intermediate, bachelors and master's degree holder respectively.

Table - 2 Gender Distributions

\begin{tabular}{ccc}
\hline Gender & Frequency & Percent \\
\hline Male & 162 & 59.8 \\
Female & 109 & 40.2 \\
Total & 271 & 100.0 \\
\hline
\end{tabular}

Table 2 shows those 162 males and 109 females answered out of a total of 271. The needed number of respondents ( 271 for our study) is ensured by recurrence conveyance, as shown in table 2. Gender 
males (162) have a larger frequency than females (109), as shown in table 2. Furthermore, the feedback of forecasted cluster has been replied as per given survey questionnaires, which also supports our study.

Table -3 Age Distributions

Ages Frequency

Percent

$\begin{array}{cc}60 & 22.1 \\ 184 & 67.9 \\ 6 & 2.2 \\ 10 & 3.7 \\ 11 & 4.1 \\ 271 & 100.0\end{array}$

The above table 3 shows the dispersion of respondents regarding the age, containing $22.1 \%$ (percent) aged 20 years lesser, 67.9\% (percent) aged 20-30 Years, $2.2 \%$ (percent) aged between 3140 Years, $3.7 \%$ (percent) were among $41-50$ Years and only $4.1 \%$ were above 50 years. The major proportion of defendants lies among 20 years less $22.1 \%$ (percent) and 20-30 of age i.e., $67.9 \%$ which support our target respondents.

Table- 4 Job Experiences

\begin{tabular}{ccc}
\hline Experience & Frequency & Percent \\
\hline 5 Years Less & 215 & 79.3 \\
$6-10$ & 22 & 8.1 \\
$11-15$ & 14 & 5.2 \\
16 and above & 20 & 7.4 \\
Total & 271 & 100.0 \\
\hline
\end{tabular}

The above given table 4 shows the dissemination of respondents which based on number of years and experiences. The highest number of respondents $79.3 \%$ (percent) has a work experience5 years less and the lowest is $11-15 y$ years which is $5.2 \%$ (percent). Therefore, the job experiences of respondents also support our targeted clusters.

The professional experience pie chart identifies many employees are working in telecom sector having less than 5 years of the experiences, which also supports our study.

Table-5 Education Qualification

\begin{tabular}{c|c|c|}
\hline Qualification & Frequency & Percent \\
Secondary & 5 & 1.8 \\
Higher Secondary & 56 & 20.7 \\
Bachelors & 149 & 55.0 \\
Masters & 60 & 22.1 \\
M.Phil/PhD & 1 & .4 \\
\hline
\end{tabular}

Table - 5 shows the distribution of respondents $1.8 \%$ (percent) individuals have secondary school qualification, $20.7 \%$ (percent) employees have Intermediate, $55.0 \%$ (percent) have Bachelors Qualification, 22.2\% have Master and finally .4\% (percent) holding doctoral degree. Maximum respondents were having Bachelors educational qualification.

\section{Descriptive Statistics with reference to Study Variables}

Data was reviewed for missing and excessive values before going on to descriptive variables, according to the study. The most extreme missing value is not founded in the data. The main objective to check the descriptive of the data by the value of skewness and kurtosis showed in the below mentioned data table no 5 . 
Table - 6 Descriptive Statistics of Study Variables

\begin{tabular}{cccccccc}
\hline Variable & Mean & $\begin{array}{c}\text { Std. } \\
\text { Deviation }\end{array}$ & \multicolumn{2}{c}{ Skewness } & Kurtosis & $\begin{array}{c}\text { Cronbach's } \\
\text { Alpha }\end{array}$ \\
& Statistic & Statistic & Statistic & $\begin{array}{c}\text { Std. } \\
\text { Error }\end{array}$ & Statistic & $\begin{array}{c}\text { Std. } \\
\text { Error }\end{array}$ & \\
\hline $\begin{array}{c}\text { Organisational } \\
\text { Identification }\end{array}$ & 4.1236 & .63033 & -1.090 & .148 & 2.334 & .295 & 0.761 \\
$\begin{array}{c}\text { Internal Branding } \\
\begin{array}{c}\text { Employee } \\
\text { Engagement }\end{array}\end{array}$ & 3.8835 & .79593 & -2.048 & .148 & 7.604 & .295 & .895 \\
\hline
\end{tabular}

The table above shows the average, normality and standard deviation and reliability of data for the instruments used in this study. Fidel et al. 2013 suggested that the values of skewness and kurtoses should be less than +1.5 and more than -1.5 . The results of the table above show that the collected data meet the specific limits of skewness or kurtoses and therefore, there is an acceptable normality. Cronbach's alpha is used as the most common and accepted measure of the internal consistency of the instruments used in the given study (Sekaran \& Bougie, 2010). The resulting values indicate how well the scale measures which must be measured continuously. The accepted value for Cronbach's alpha is 0.6, while values above 0.9 are considered abnormal (Sekaran \& Bougie, 2010). The alpha values of Cronbach obtained in this study show that they are within the acceptable values suggested by the researchers. The internal branding Alpha Cronbach is 0.895 and contains 12 components. The tool used in the organizational identification is 0.761 and contains 6 items.

The third instrument used in this study is to measure employee engagement. Cronbach has an alpha value of 0.839 and contains 08 items. Therefore, all of Cronbach's alpha values are within the recommended limits.

\section{Correlation Analysis}

The most complete Pearson product moment correlation or PPMC, commonly known as Pearson correlation, is the linear relationship between two datasets, and the interdependence between data sets is a measure of their relationship (Pearson, 1895) shows. Pearson's link is represented by two letters: A population is represented by the Greek letter rho, while a sample is represented by the letter "r." It also reveals the direction of the link between the variables under investigation. The outcome will be either positive or negative, with a value between -1 and 1 . The data points will vary about the more appropriate line, and the value of $r$ will be near to zero. In elevation the correlation value might range from 0.5 to 1.0 or from -0.5 to 1.0 . The average correlation can be 0.3 to 0.5 or -0.3 to -0.5 and 0.1 to 0.3 or -0.1 to -0.3 is a weak association (Cohen, 1988). In order to determine the correlation between all variables in our study, Pearson's correlation will be employed to describe the collinearity matrix.

Table -7 Correlations

\begin{tabular}{|c|c|c|c|}
\hline Variables & $\begin{array}{l}\text { Organizational } \\
\text { Identification }\end{array}$ & $\begin{array}{c}\text { Internal } \\
\text { Branding }\end{array}$ & $\begin{array}{c}\text { Employee } \\
\text { Engagement }\end{array}$ \\
\hline Organizational Identification & 1 & & \\
\hline Internal Branding & $.420 * *$ & 1 & \\
\hline Employee Engagement & $.276^{* *}$ & $.599 * *$ & 1 \\
\hline
\end{tabular}

The table shows how organisational identity correlates with Pearson's correlation matrix the result was found positive relation with the participation of employees $(r=0.420, P<0.01)$. Moreover, there is a strong positive link between the two variable internal branding and employee engagement $(\mathrm{p}$ $<0.01)$ and $\mathrm{r}=0.276$ ) 


\section{Regression Analysis}

Linear regression analysis is a statistical technique for examining the relationship and effect between the variables under investigation. Here it was tried to find out the effect of a variable(s) on other variable(s) under study, to measure the relationship between the relationship between Organisational Identification, Internal Branding and employees' engagement, simple linear regression in SPSS is used.

The significant positive value represents a positive relationship. Instead, the large negative value of beta represents the inverse between the two variables relationship. Also, if the value is significant, then there will be no relationship.

\section{Table -8 Model Summary}

\begin{tabular}{cccccc}
\hline Model & $\mathbf{R}$ & R Square & $\begin{array}{c}\text { Adjusted R } \\
\text { Square }\end{array}$ & $\begin{array}{c}\text { Std. Error of the } \\
\text { Estimate }\end{array}$ & Sig. F Change \\
\hline 1 & $.599^{\text {a }}$ & .359 & .354 & .66244 & .000 \\
a. Predictors: (Constant), Internal branding and Organisational Identification \\
b. Dependent Variable : Employee Engagement
\end{tabular}

As per the model summary of table 10 shows that both hypotheses are internal branding and organisational identification independent variables has a positive relation with the dependent variable which is employees' engagement. The $\mathrm{R}$ value depicted that represents the simple correlation between the independent variables; internal branding and organisational identification and employees' engagement. The $\mathrm{R}$ value is .599 that shows strong correlation exists between variables. The $\mathrm{R}$ square value also demonstrates how the independent variables can explain a considerable portion of the overall variance in the dependent variables.

Hence the R Square value is .359 which is approximately $55 \%$ of variance of the independent variables can be explained with dependent variable which is higher than the average. The above table also shows Sig. F Change value 0.00 which signification \& data is normally distributed.

Furthermore, the R Square value is .359 which shows that $35.9 \%$ variation in organisational identification and internal branding are explained by employee engagement.

Table -9 ANOVA ${ }^{\mathrm{a}}$

\begin{tabular}{|c|c|c|c|c|c|c|}
\hline & Model & Sum of Squares & Df & Mean Square & $\mathbf{F}$ & Sig. \\
\hline \multirow[t]{3}{*}{1} & Regression & 68.356 & 2 & 34.178 & 81.475 & $.000^{\mathrm{b}}$ \\
\hline & Residual & 112.424 & 268 & .419 & & \\
\hline & Total & 180.780 & 270 & & & \\
\hline
\end{tabular}

a. Dependent Variable: Employee Engagement (EE)_Mean

b. Predictors: (Constant), Organizational Identification (OI)_Mean, Internal branding (IB)semen

This above table shows about ANOVA test which this test is used to assess the model's fitness and it can also be used to check variance. At a significance level of.000, the regression model is highly significant. The F statistic evaluates the model's fitness, and the standard value for the F statistic is 8 . This study's model was fitted with an $\mathrm{f}$ value of 81.475 and a significance level of. 000 . The result demonstrates that the regression model has a considerable impact of the outcomes of the variable. It further proves that the both models are demonstrating significant difference between the means of the variables. 
Table -10 Coefficients

\begin{tabular}{|c|c|c|c|c|c|c|}
\hline \multirow{2}{*}{\multicolumn{2}{|c|}{ Model }} & \multicolumn{2}{|c|}{$\begin{array}{l}\text { Unstandardized } \\
\text { Coefficients }\end{array}$} & \multirow{2}{*}{$\begin{array}{c}\text { Standardized } \\
\text { Coefficients } \\
\text { Beta }\end{array}$} & \multirow[t]{2}{*}{$\mathbf{T}$} & \multirow[t]{2}{*}{ Sig. } \\
\hline & & $\mathbf{B}$ & Std. Error & & & \\
\hline & (Constant) & 1.663 & .283 & & 5.873 & .000 \\
\hline 1 & $\begin{array}{l}\text { Organisational Identification } \\
\text { (OI)Mean }\end{array}$ & .039 & .070 & .030 & 6.555 & .000 \\
\hline & Internal Branding (IB)Mean & .607 & .056 & .586 & 10.880 & .000 \\
\hline
\end{tabular}

The coefficient table is used to check each variable's association one by one. We can see the Beta and significance value in this table. At positive Beta values of.030 and.586 respectively, the association between the variables is substantial. The results given in table above shows the strong association between organisational identification and employee's engagement (Direct link between IV and DV) and between internal branding and employees' engagement (IV and DV direct relationship); As a result, the findings show that all variables have strong associations that are highly significant (p.01).

Table -11 Summary of Hypotheses

\begin{tabular}{lccccc}
\hline Hypotheses & B & T-Value & P-Value & Remarks \\
\hline $\begin{array}{l}\text { H1. There is a positive and significant impact of } \\
\text { organizational identification on employees' engagement. }\end{array}$ & .039 & 6.555 & 0.00 & Accepted \\
$\begin{array}{l}\text { H2. There is a positive and significant impact of internal } \\
\text { branding on employees engagement. }\end{array}$ & .607 & 10.88 & 0.00 & Accepted
\end{tabular}

\section{CONCLUSION}

The relationship between employee's engagement and organizational identity has been proved with the 0.003 cost. Hypothesis 1 claims that employee's engagement has an impact on the organizational identification. The results verify the hypotheses by proving the positive impact of organizational identification with employee's engagement. Similarly, the relationship between employee engagement and internal branding is very significant, with a $\mathrm{P}$ value of 0.003 . Therefore, Speculation 3 is also confirmed. Increase employee involvement in the organisation through improving internal branding. Over the past three decades, the trend of job careers has been considered by many different organizations due to some possible changes within the business It has evolved into a work-focused mind-set, as well as job satisfaction and performance. Employee involvement, he said as "the use of organizational members. A key independent variables organisational identification and internal branding has been added to the conceptual model, which deals with the relationship between organizational identity, internal branding and employee engagement." Domestic brand is an important indicator for employees. The interaction of this has a significant effect on the employment rate of employees' level of employee communication. According to Gilman (2000), employees are the main people in the organization who have tasks to do the job. Their responsibilities and duties the success of the organization through participation, and research, can now be summarized to show how the affects organizational identity, and internal branding through employee interaction.

\section{RECOMMENDATIONS}

A cross-border analysis can be carried out in the same way. Note any other sampling approach, such as probability sampling, can be applied to this problem. The current research concerns telecommunications companies in Rawalpindi and Islamabad and could be extended to other service providers. To influence employee engagement, the organizational model can include new projects such as organizational culture, value sets, active participation, and organizational grouping. Longitude 
analysis can be performed to understand employee perceptions of the work environment, as perceptions generated by employee changes also improve or worsen over time. More about this source text Source text required for additional translation information.

\section{REFERENCES}

Albrecht, S.L., \& Andretta, M. (2011). The influence of empowering leadership, empowerment and engagement on affective commitment and turnover intentions in community health service workers: Test of a model. Leadership in Health Services, 24(3), 228-237.

Ashforth, B. E., \& Mael, F. (1989). Social identity theory and the organization. Academy of management Review, 14(1), 20-39.

Ashforth, B. E., Harrison, S. H., \& Corley, K. G. (2008). Identification in organizations: An examination of four fundamental questions. Journal of Management, 34(3), 325-374.

Biotic, D. (2013). Relationship between Working Conditions and Job Satisfaction: The Case of Croatian Shipbuilding Company. International Journal of Business and Social Science, 206214.

Bandura, A. (1977). Self-efficacy: Toward a unifying theory of behavioural change. Psychological Review, 84(2), 191-215.

Bandura, A. (1982). Self-efficacy mechanism in human agency. American Psychologist, 37(2), 122147.

Bandura, A. (1986). Social foundations of thought and action: A social cognitive theory: PrenticeHall, Inc.

Bendixen, T. M. P (2015). The impact of internal band management on employee job satisfaction, brand commitment and intention to stay. International journal of bank marketing, 33(1), 1-9.

Bergami, M., \& Bagozzi, R. P. (2000). Self-categorization, affective commitment and group selfesteem as distinct aspects of social identity in the organization. British Journal of Social Psychology, 39(4), 555-577.

Brown, T. A. (2006). Confirmatory factor analysis for applied research. New York, NY: Guilford.

Carter wright, S., \& Holmes, N. (2006). The meaning of work: The challenge of regaining employee engagement and reducing cynicism. Human resource management review, 16, 199-208.

Chernatony, D. L. (2001). Corporate branding and corporation brand performance. Europe journal of marketing, 35(4), 441-456.

Conger, J., \& Kanungo, R. (1988). The empowerment process: integrating theory and practice. Academy of Management Review, 13(3), 471-482.

Cronbach. L. J. (1951). Coefficient alpha and the internal structure of tests. Psychometrika, 16 (3), 297-334.

Daft, R., \& Marcic, D. (2001) Understanding management, Boston: South western Thomson Learning.

De Nobile, J. J., \& McCormick, J. (2008). Organizational communication and job satisfaction in Australian Catholic primary schools. Educational Management Administration \& Leadership, 36(1), 101-122.

Deci, E. L. (1971). Effects of externally mediated rewards on intrinsic motivation. Journal of Personality and Social Psychology, 18(1), 105-115.

Diamond, M. A., \& Allcorn, S. (1985). Psychological dimensions of role use in bureaucratic organizations. Organizational Dynamics, 14 (1), 35-39.

Dickson, E. K. (2009). Psychological empowerment and job satisfaction of temporary and part time Non standard Workers: A preliminary Investigation. South East Missouri State university South illinosia.

Diehl, M. (1990). The minimal group paradigm: Theoretical explanations and empirical findings. European Review of Social Psychology, 1(1), 263-292.

Dormann, C., \& Zapf,D. (2001). Job satisfaction: A meta-analysis of stabilities. Journal of Organizational Behavior, 22, 483-504.

Dutton, J. E., Dukerich, J. M., \& Harquail, C. V. (1994). Organizational images and member identification: Administrative Science Quarterly, 39, 239-263 
Dyne, V., Cummings, L. L., \& Parks, J. M. (1995). Extra-role behaviors: In pursuit of a construct and definitional clarity (a bridge over mudded waters). Greenwich, CT: JAI Press.

Edwards, M. R., \& Peccei, R. (2007). Organizational identification: Development and testing of a conceptually grounded measure. European Journal of Work and Organizational Psychology, $16(1), 25-57$.

Einwiller, S., \& Will, M. (2000). Corporate Branding Study - Theoretical Concepts and Empirical Findings. St. Gallen: MCM Institute.

Eylon, D., \& Bamberger, P. (2000). Empowerment cognitions and empowerment acts. Group \& Organization Management, 25(4), 354-372.

Firebaugh, G., \& Harley, B. (1995). Trends in job satisfaction in the United States by race, gender, and type of occupation. Research in Sociology of Work, 5, 87-104.

Gecas, V. (1989). The social psychology of self-efficacy. Annual Review of Psychology, 15, 291-316.

Ghasemi A., \& Zahediasl. (2012). Normality test for statistical analysis: a guide for non-statisticians. International journal Endocrinol Metab, 10, 486-489.

Gioia, D. A., Schultz, M., \& Corley, K. G. (2000). Organizational identity, image, and adaptive instability. Academy of Management Review, 25(1), 63-81.

Gist, M. E. (1987). Self-efficacy: Implications for organizational behavior and human resource management. Academy of Management Review, 12(3), 472-485.

Goffman, E. (1961). Encounters: Two Studies in the Sociology of Interaction - Fun in Games \& Role Distance, Indianapolis. Bobbs Merrill.

Gull, S., \& Ashraf, S. M. (2012). Impact of internal branding on service employees: quality commitment-study on education sector of Pakistan. International Journal of Business and Social Science, 3(14), 302-311.

Hackman, J. (1987). The design of work teams. In J. W. Lorsch (Ed.), Handbook of organizational behaviour, 315-342. Englewood Cliffs, NJ: Prentice-Hall.

Hackman, J. R., \& Oldham, G. R. (1980). Work redesign. Reading, MA: Addison-Wesley.

Hair, J. Anderson, R. Tatham, Black. W. (1998). Multivariate Data Analysis, 5 Edn. Prentice Hall International, London.

Hall. A., \& Wang. T. (2005). Two-component mixtures of generalized linear mixed effects models for cluster correlated data. Statistical Modelling, 5, 21-37.

Harter, J. K., Schmidt, F. L. \& Hayes, T. L. (2002). Business-unit-level relationship between employee satisfaction, employee engagement, and business outcomes: A meta - analysis. Journal of Applied Psychology, 87, 268-279.

Hasanzadeh. M. (2013). Job satisfaction as a mediator i relationship between involvement Managerial and job performance among bank employee in kerman. Indian journal of fundament and applied life series, 3, 2231-6345.

Haslam, S. A., Ellemers, N., van Knippenberg, D., \& Platow, M. (2003). Social identity at work: Developing theory for organizational practice. New York: Psychology Press.

Hogg, M. A. (2006). Social identity theory. In P. J. Burke (Ed.), Contemporary social psychological theories, 13, 111-1369. Stanford, CA: Stanford University Press.

Hongwe, H. (2012). Procedual justice and employee engagement: Role of organizational identification and moral identity Centrality. Journal of Business Ethics.

Hoppock, R. (1935). Job Satisfaction: Harper and Brother, New York.

Iiacqua, J. A., \& Schumacher, P. (1995). Factors contributing to job satisfaction in higher education. Education, 116(1), 51-66.

Jawale, V. (2012). Methods of sampling design in the legal Research: Advantages and Disadvantages. International Interdisciplinary Research journal, 2, 183-190.

Jones, G., George, J., \& Hill, C. (2000). Contemporary management, Boston: Irwin McGraw Hill.

Jose, G. (2014). Phyclogical empowerment as a predictor of employee engagement. An empirical Attestation. Global Business review, 15, 93-104.

Kalleberg, A. L. (2000). Nonstandard employment relations: Part-time, temporary and contract work. Annual Review of Sociology, 26, 341-365.

Lee, K., Kim, S., \& Kim, Y. S. (2013). The impact of internal branding on employee engagement and outcome variables in the hotel industry. Asia pacific journal of tourism research, 19, 13591380. 
Malone, T. W. (1997). Is empowerment just a fad? Control, decision making, and IT. Sloan Management Review, 38(2), 23-35.

Marius, W.S. (2010). Phyclogical empowerment, job insecurity and employee engagement. Journal of industrial psychological, 36, 1.

McQuitty, S. (2004). Statistical power and structural equation models in business Research. Journal of Business Research, 57 (2), 175-83.

Mersham, G. \& Skinner, C. (1995). Corporate social responsibility in South Africa: emerging trends Society and business Review, 3, 239-255.

Milkovich, G. T., \& Boudreau, J. W. (1997). Human resource management. Burr Ridge, IL: Irwin.

Rabbie, J. M., \& Horwitz, M. (1969). Arousal of ingroup-outgroup bias by a chance win or loss. Journal of Personality and Social Psychology, 13(3), 269-277.

Rafiq, M., \& Ahmed, P. K. (2000). Advances in Internal Marketing Concept: Definition, Synthesis and Extension. The Journal of Services Marketing, 14 (6), 449-462.

Rawat, S. P. (2011). Effect of psychological empowerment on commitment of employees: An empirical study. Second international conference on humanities. Historical and social sciences, Singapore.

Riketta, M. (2005). Organizational identification: A meta-analysis. Journal of Vocational Behaviour, 66(2), 358-384.

Robinson, D., Perryman, S. and Hayday, S. (2004). The Drivers of Employment Engagement, Brighton, Institute for Employment Studies.

Rothbard, N. P. (2001). Enriching or depleting? The dynamic of engagement in work and family roles. Administrative Science Quarterly, 46(4), 655-684.

Rothman, R. A. (1987). Working: Sociological perspectives. Englewood Cliffs, NJ: Prentice-Hall.

Seibert, S. E., Silver, S. R., \& Randolph, W. A. (2004). Taking empowerment to the next level: A multiple-level model of empowerment, performance, and satisfaction. Academy of Management Journal, 47(3), 332-349.

Staw, B. M., Bell, N. E., \& Clausen, J. A. (1986). The disposition approach to job attitudes: A lifetime longitudinal test. Administrative Science Quarterly, 31, 56-77.

Summer, W. G. (1906). Folkways: A study of the sociological importance of usage, manners, customs, mores, and morals. Oxford, England: Ginn. 